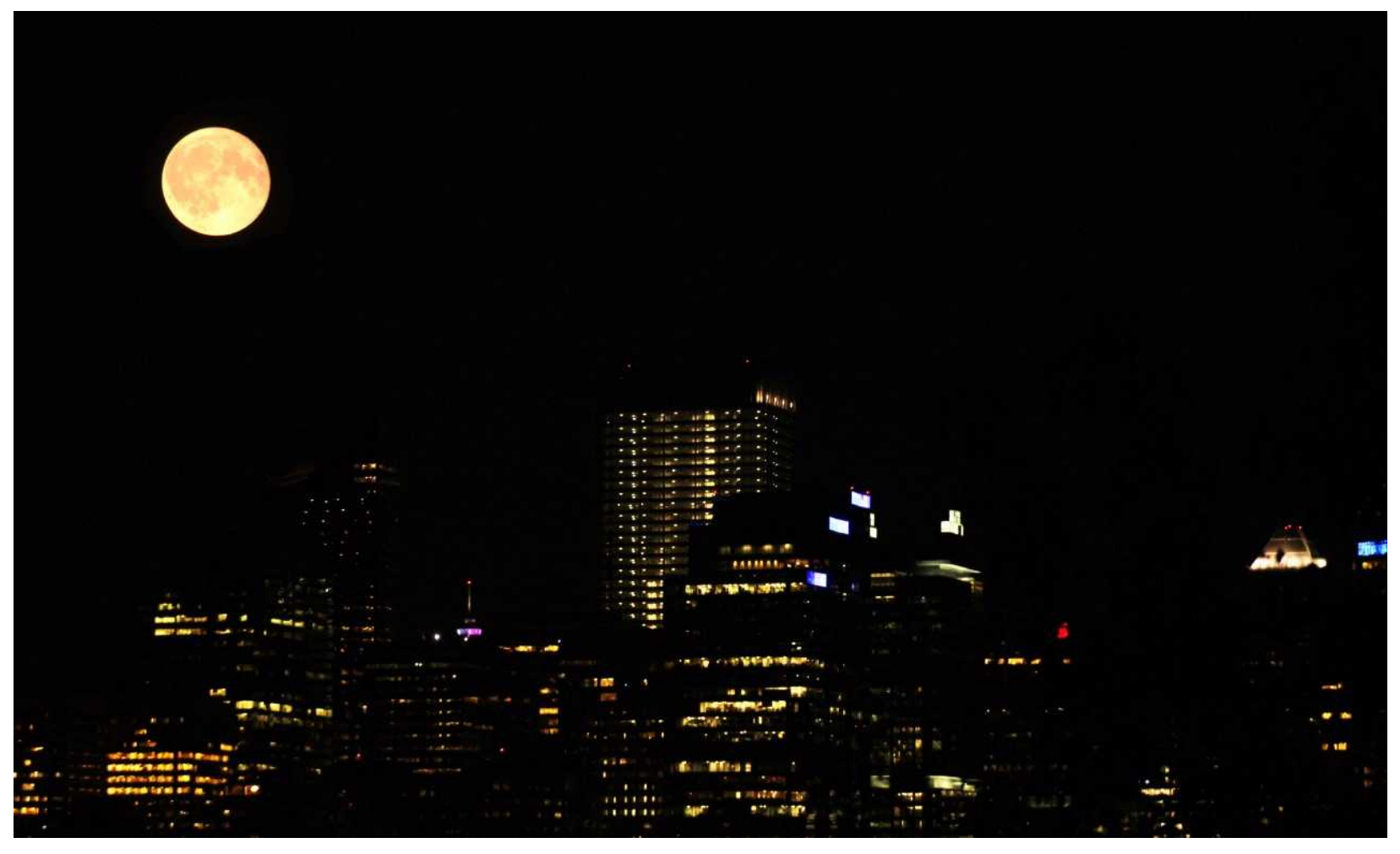

Danielle Quackenbush, The Night Sun, 2017

Digital photography 


\title{
Transitions and Transformations: Extracts from a Duoethnographic Exploration of Gender Identities in Canada and China
}

\author{
Elizabeth McNeilly \\ University of Calgary \\ elizabeth.mcneilly@ucalgary.ca \\ Ling Lei \\ University of Calgary \\ ling.1ei@ucalgary.ca
}

\begin{abstract}
Employing the research method of duoethnography, two researchers participate in a co-learning journey, making meaning of their personal stories through writing, critical reflections and theoretical discussions about gender identities. By sharing narratives concerning their significant lived experiences, the researchers compare and contrast major cultural and economic influences on themselves and their families. The authors demonstrate in vivid ways how their perceptions of their identities as girls, women, and mothers have changed over time. Through this process, they create a platform to discuss ways in which their identities and life experiences have been and continue to be influenced by societal and institutional expectations.
\end{abstract}

Keywords: Gender identities, participatory inquiry, extended epistemology, duoethnography

\section{Prologue}

The photograph, 'The Night Sun', is a picture of light and darkness. It shows a full moon, shining over Calgary, Alberta, Canada. The moon illuminates stark structures of a modern, western, culture-bathed city. The photograph contrasts the natural (the moon) with the artificial (the man-made physical, structures).

The moon's light reflects the rays of the blinding sun's light, hidden from us at night. During our journey of exploring gender issues and its hidden aspects, we shone the sun - and at times, moonlight - on our respective cultures, in order to show commonalities, differences and variations in our respective socialization processes of becoming women and mothers.

\section{Introduction}

Our cultures, families and significant others help to shape, constrain and change our gender identities. As importantly, life experiences in different cultures can reaffirm or precipitate significant relearning, unlearning and transforming of gender identities. Further, we feel that it is imperative to initiate more intentional and authentic intercultural conversations that examine the underlying driving forces and assumptions concerning gender roles, expectations and resultant inequalities between women and men. This paper echoes the theory of extended epistemology (Heron, 1981) which extends ways of knowing from the predominant form of propositional knowing to include the importance of knowing through lived experiences and artistic expressions.

Cultural and Pedagogical Inquiry, Summer 2018, 10(1), pp. 62-77

ISSN 1916-3460 (C) 2018 University of Alberta

http://ejournals.library.ualberta.ca/index.php/cpi/index 
Employing the research method of duoethnography (Ellis, 1977; Norris and Sawyer, 2012; Lund and Evans, 2006; Madison, 2012; Oberg and Wilson, 2002; Wall, 2006), we participated in a co-learning journey, making meaning of our personal stories through writing, critical reflections, and theoretical discussions about gender identities and respective roles played by women and men in families, institutions and societies. By sharing narratives concerning, our lived experiences, we juxtapose sharp differences and similarities regarding gender identities in our countries. We reflect on the impacts of significant others, and discuss our changing perceptions of our identities as girls, women, and mothers.

Initially, the Canadian researcher (Elizabeth), reflects on her personal experiences of her child transitioning; negotiating identity as a woman missionary in Japan; and learning about nonwestern cultures that accept and value, 'non-conforming' gender identities.

The Chinese researcher (Ling), reflects on childhood experiences of growing up in a lone-parent family in China; learning to perform gender as a young woman; and discovering a woman's societal worth when becoming a mother with a daughter. Issues of gender equality and inequality are fundamental issues of human rights. Furthermore, we argue that gender inequities are maintained by capitalism and colonialism. Both systems sustain social hierarchies of power and oppression in Canada and China.

\section{The Context}

Elizabeth: Interesting enough, our conversations about gender began without words. We were students in a challenging, graduate level, Adult Learning class, sharing transformational moments that we had had throughout our lives. I spoke of my love/hate relationship with being a woman, in terms of, the limitations, frustrations, and expectations placed on me because of my gender. As I shared a painful yet defining experience I had while in university in 1988, I noticed that a tear had escaped Ling's eye. Ling, the powerful, bright young woman who seemed to know English better than me! It is shocking at times when we open up and find others, unexpectedly, who share our stories. We see in others similarities that we did not expect to see. It is a relief to reaffirm, that despite cultural differences, we are all human.

We began with "letters" to each other. I suppose the idea was a romantic one for me; a former English teacher, writing and sending epistles with my deepest darkest thoughts, and then anticipating eagerly, my confidante's reply. Our shared frustrations of gender united us, yet Ling, was raised in China and I in Canada. We were both mothers. Despite our similar starting points of a shared gender, our standpoints varied. The differences would enrich our narratives and analyses as we ping-ponged ideas back and forth through a series of emails.

\section{The Letters Unfold}

\section{$\sim$ Elizabeth}

The rites of passage of manhood in many cultures was not only a medium for training strong young men, but to identify the weak, inadequate ones and punish them for being like "women" (Brown, 2017). When talking with Ling, I noted that despite our geographical and national differences, our love/hate relationships with gender were quite similar. Further, that the rites of passage for womanhood, though different, generated similar results. We were two strong women, both angry at the misogynistic dominant cultures, rebellious against traditional

Cultural and Pedagogical Inquiry, Summer 2018, 10(1), pp. 62-77

ISSN 1916-3460 C 2018 University of Alberta

http://ejournals.library.ualberta.ca/index.php/cpi/index 
expectations of women, embracing higher education to challenge ourselves and cultures, and at the same time, living lives in the embrace of motherhood.

For my part, I was born in Winnipeg, Manitoba, Canada. My father, from Liverpool England, met my mother, from Ontario, in the Canadian Air Force. During my childhood, I lived in different places, in Manitoba, Nova Scotia, Ontario, and Alberta. After attending and graduating from the University of Ottawa, I went on an 18-month Mormon, church mission to Japan where I was immersed in an unfamiliar Buddhist/Shinto culture. The Japanese people did not equate Christianity with love and goodwill. Accordingly, trying to convert them to Christianity was not easy. This was also my first experience with men from another culture, men who did not share the history of chivalry as I had been taught in Canada. Doors were not held open for me and I resented it. At age 21, I judged the Japanese men according to, the only standards I knew.

I married an American, moved to the US and lived in Utah, Florida, Illinois, California, and Maryland. We had two girls and when they were young, I had a crisis of faith and a schism with my church. After much depression and distress, I studied not only my religion with fervor, but examined the whole concept of God. Eventually, like a house of cards, I saw the pieces of my religious beliefs flutter to the ground. I began my life anew-with no doctrine to guide me and a moral compass wiped clean of its fixed, due north location. Instead, I judged the world on my own terms, yet often with a split mind. The residue of years of Christian teaching simply held its sway against the new teachings I was learning through extensive reading.

When my youngest child transitioned, the world of gender issues swung into full view. I could not discuss it casually or study its complexity because I had a 13-year-old who desperately wanted me to understand. Who demanded I understand. I thought that my child needed to understand the beauty of womanhood, like I had learned about it through many tears during the years. At the time, I thought she couldn't become a man; that would be treasonous. Wouldn't it?

\section{$\sim$ Ling}

In class, when I heard you saying that your daughter was transgender, I felt a bit shocked. My mind was filled with questions: How hard would it be to raise a transgender kid? How did you come to terms with this fact, to be able to overtly talk about it, in what appeared to be a neutral tone? Why did your daughter feel compelled to physically change her gender? Had she also confessed to her peers about the change in her gender orientation? When you talked about the rites of passage for womanhood and two women's rebellion against traditional female expectations, I was wondering if your daughter was acting in defiance of the societal, female expectations she had perceived and learned.

For me, the socio-culturally imposed gender expectations have significantly shaped my personal growth and my perceptions of self-worth and identity as a woman. Nevertheless, I was somehow blind to their pervasive influences, until those influences emerged as the topic and theme that led me through the writing of a required university course assignment, my educational biography. The process of writing the biographical narrative kept triggering memories and reflections on how I learned my identity as a girl and woman. I was raised in a blue-collar, single-parent family in suburban Chongqing, a then underdeveloped city in inland China. My mother used to have a bright, good-looking son before I was born. She enjoyed an ordinary yet, happy marriage. My father was a hardworking technician with promising career advancement

Cultural and Pedagogical Inquiry, Summer 2018, 10(1), pp. 62-77

ISSN 1916-3460 (C) 2018 University of Alberta

http://ejournals.library.ualberta.ca/index.php/cpi/index 
opportunities. Their son exhibited enviable talent. She could have had a blessed destiny leading a satisfying life, if it were not for the sudden and unexpected disappearance of their nine-year-old son. The vain search for the boy struck the family, devastatingly. My mother told me that she wept almost every day, not knowing whether her son was alive or not. She would frequent the school areas to see children, being kissed and hugged by their mothers, only to find that nobody was waiting to be picked up by her and be called son. At that time, child trafficking was rampant in China. Yet, my mother was sustained by the hope of her son finding his way home.

It took two years for my parents to finally accept the loss of their son. Father suggested the need to have another child, and I was born. "Unluckily," mother gave birth to a girl. In every way, I looked different to their long-lost son. Unfortunately, by giving birth to me, they used up their only chance of having a son because the government enforced a one-child policy. For as long as I could remember, I was told by mother that my father was angry and disliked me because I was a girl. I remember that he took his anger out on my mother. He abused my mother and demanded a divorce when I was only one year old. After the divorce, my mother raised me by herself. Sometimes, she would look back on her days as a divorced mom with a positive note, proudly commenting on how she made herself a strong woman, and an all-around undefeatable person, but as far as I observed, poverty, loneliness, public contempt and bullying had sadly, converted a lovable woman into a quarrelsome, cynical and defensive neurotic.

It is definitely through my mother's inculcation of values and by observing her miserable experience that I earned my rite of passage to womanhood. I realized that a woman has to be tough, that I have to prove myself, by excelling in everything, and that I had to demonstrate that a woman is not inferior to a man. I remember that I worked hard in school and maintained top academic rankings to please my mom. During the parents'-teachers' meetings, her face lit with pride when the teacher praised me for having set an academic and moral example for the fellow students. I remember how insulted I felt when I ranked second to a boy student in the final exams. I remember enjoying racing with boys in the track and field events and defeating boys in ping-pong games. However, it was gradually, through my own marriage and workplace experiences that I came to understand that toughness of womanhood is always constrained and contained by the larger society, within acceptable degrees and limits. Our culture demands that womanhood possess a soft facet. An old Chinese saying states: "a woman will doll herself up for him who loves her." Women have to cater to men's ideas of beauty in order to become domesticated by their husbands and their male superiors. Seemingly, untameable and tough women, such as women doctoral students, who are considered uninterested in dolling themselves up, are quite often condemned for being single, and thus deemed a social problem in China. Therefore, women who aspire to pursue a doctoral degree are cautioned to get married before starting their doctoral programs. It seems that womanhood is regulated by manhood. Women have to carefully navigate through womanhood with men as being the north point on their individual compasses.

I mentioned earlier that I was previously blind to the obvious gender expectations imposed on me, but when I reflected on my mother and my own painful experiences living in a single-parent family, I now think that I may have been reluctant to directly face, discuss and address gender issues. However, like your daughter demanding your understanding of her problem, becoming a mother of a baby daughter myself, has prompted me to untangle my mixed thoughts and emotions towards gender.

Cultural and Pedagogical Inquiry, Summer 2018, 10(1), pp. 62-77

ISSN 1916-3460 (C) 2018 University of Alberta

http://ejournals.library.ualberta.ca/index.php/cpi/index 
I had always hoped that I could have a boy. Because my father wished to have a son, my mom suffered without a son. My husband indicated that he preferred a boy, and people from northeast region of China where my parents-in-law reside are generally known to favour grandsons. I felt that I had the obligation to give birth to a boy. So when I was told that I was going to have a girl, my tears couldn't help pouring down. Although I reassured myself before the ultrasound exam that it would be alright if it was a girl and my husband comforted me saying that he would also like a girl, I could see a trace of disappointment in his eyes. I blamed myself for having a girl. It felt as if a daughter would undermine my own worth as a woman and wife, and the worth of my daughter was being judged even before she was born...

Now my baby daughter is 14-months old and she exhibits a personality that strongly resonates with that of being like a stereotypical boy. As my mother puts it, "She is so much like a son." Nevertheless, she is physically a girl. She doesn't have any idea whether she is acting like a boy or girl. However, I know that as she grows up, she will pick up the meaning of being a girl and woman along the way. I hope that she can appreciate and savour the beauty of womanhood, as you mentioned, but it looks to me that womanhood entails more struggle than beauty.

\section{$\sim$ Elizabeth}

The one child rule in China, I assume, heightened the value of manhood in the Chinese culture. The son, historically carries the family name, ensures an income for the family, and cares for his parents upon aging. A daughter offers no such security. As the value of male infants rose in China, female worth suffered and it appears that this pressure and preference was instilled in women, too. Both you and your mother wanted a son yourselves. You made a fascinating, yet heartbreaking, discovery that having a daughter might undermine your own worth. Thus, not only does being a daughter yourself affect your self-esteem but your presumed inability to produce a male heir cements it.

It appears that you have battled with the societal messages through academic accomplishments and by having a competitive career. Through an autobiographical course assignment at the university, you were able to see from where your drive stems. You have hinted that it was born out of poverty and the struggle of a single parent household, and yet similar structures have crushed others. Did you have role models in your life? What inspired you to move beyond the social expectations of womanhood in China? Was there someone you wanted to prove wrong? What vision kept you going?

Pauline Boss, who has studied ambiguous loss since 1973 and coined the term, stresses its paralyzing nature that can cripple a family (Boss, 2000). When my child came out to me as being transgender, I mourned because, unlike you, I had longed to have daughters and did not want a son. In one of the first conversations, after my teen came out, I said, "I think you just need to learn what it means to be a woman." I overcame my own frustrations with womanhood by this learning, and I expected my child to do the same.

My teenager proceeded to make the transition. He didn't feel frustrated being a girl, but felt more like a boy inside. This was what I would learn: my teen had always left like a boy inside. Perhaps, my son's journal entry shortly after his coming out to me, shows both of our struggles during this time:

'Kay, I know this isn't the best way to begin a journal but I feel frustrated and confused. I

Cultural and Pedagogical Inquiry, Summer 2018, 10(1), pp. 62-77

ISSN 1916-3460 (C) 2018 University of Alberta

http://ejournals.library.ualberta.ca/index.php/cpi/index 
am frustrated because I want to become more masculine and my mom doesn't completely understand. Maybe I've been hanging around Kevin [name changed] too much, but it really does make me feel happy and good when I wear boys [sic] clothes or play sports or workout or do anything masculine. Don't ask. I have no idea why I feel this way.

My mom is allowing this (boy's clothes, hair REALLY short), but I can tell she really wants this to be a quick phase. Is it a phase? I can't say; I'm doing what makes me feel good about myself and happy.

Also, Mom's last talk with me ended with, "I want you to find out the meaning of being a woman.". .. She doesn't get it. I have nothing against women. I have girlfriends and I'm attracted to them. I just want to be a man. (Date: 1-5-2011)

This journal entry was the beginning of many. Each of us struggled to discover why my child felt such discontent and dysphoria. It was only with time we realized that this was not a phase, but the need of finding himself along the gender spectrum.

I learned that gender exists not as a binary but on a spectrum. I learned that we are a mixture of inherited and cultural traits. So while part of my son's brain structure is likely male (Alicia \& Dick, 2008; Liao et al., 2012), he is only now, learning many of the social and cultural expectations, usually associated with a male culture (Edwards \& Jones, 2009; Pascoe, 2007).

At the time, I felt the pull to be traditional, to abide by gender rules. However, as every day passes, I counter the social norms and have recognized that gender variance is typical. My gender paradigm continues to shift. As I recognize how ill-informed I have been regarding gender, it makes me question my own gender identity. How much of who I am is inherited and how much was learned or mislearned? If we grew up in a culture without gender expectations, how different would I be today? Who would I be if gender roles were not enforced by those around me? With all the cultural messages in your society, Ling, how did you know that women were not inferior to men? Or did you, yourself, have to learn this?

\section{$\sim$ Ling $\sim$}

Your questions about my role models and how I came to know the issue of gender inequality, really kept me thinking. I remember that Jarvis (2006) explicated that our gender expectations are more learned through socialization in our cultures than determined by our genes. There is a hidden curriculum (Krammer \& Mangiardi, 2012) of gender in everyday life that we tacitly, internalize and play out. When looking back, I believe my very first lessons of this hidden curriculum of gender were taught by my mom. She used to be my role model when I was a small child. Despite all the misfortunes, she was always a tough and strong-willed woman. She told me that when she was promoted to being a sales supervisor, nobody would obey her. She went to great lengths to enforce her leadership. It was only after her teammates obtained a higher monthly, sales bonus under her leadership that she gradually won her colleagues' respect. I also remember her encouraging me to strive for excellence in school because "it is the only way for others to look up to us." Thus, my mom instilled in me the view that respect is earned and that I must work hard to earn it. As I reflect on my childhood now, I think that I may have been too focused on my own striving to earn respect, equal rights and opportunities to realize that any gender inequality existed. Since I believed that diligence is the only means for a disadvantaged woman to succeed in life, gender inequality to me was my own fault for not trying hard enough.

Cultural and Pedagogical Inquiry, Summer 2018, 10(1), pp. 62-77

ISSN 1916-3460 @ 2018 University of Alberta

http://ejournals.library.ualberta.ca/index.php/cpi/index 
When I entered into adulthood, people carrying a different curriculum of gender came into my world. As I had spent my middle school years in a full-time boarding school and later migrated to Beijing to pursue higher education, my mom's influence on me was becoming distant. My best friend in high school, Xing, was one of my dorm mates. She was born into a very happy and well-off family. She was pretty, upbeat and smart. Her boyfriend was fascinated with her and had dated her since they were classmates in junior high school. It was interesting that a girl so unlike me became my best friend. One day, during noon break in our dorm, I was sitting at the table reading with my hair hanging down loosely when Xing, sitting across the table, commented that I looked prettier with my hair down and suggested that I keep it down in school. I got very nervous with this genuine praise of my physical attractiveness.

I realized that I had kept my hair short above the neck in a boy's hairstyle throughout junior high school. I had been intentionally keeping myself looking physically neutral maybe because I thought that it made me appear tough. On another occasion, Xing also suggested that I wear skirts and dresses rather than trousers all year round. I didn't get the point then. I was obtuse in learning what it means to be a woman.

Perhaps it was during the university years that I truly came to have a sense of womanliness. I was 19 when I became a freshman. It was the first time for me to be so far away from home and I felt excited to start my new life in Beijing. Then I became attracted to my first boyfriend. He was a native Beijinger and enjoyed teaching me how to dress up like an attractive Beijing girl. Maybe trying to fit in to my boyfriend's female expectations was a way of adapting to the mainstream of the new social environment. A desirable woman should be like Xing, physically attractive, upbeat, and smart. Elizabeth, did you hold certain presumptions when you said to your daughter that she needed to know what it meant to be a woman?

The recollection of my past memories reminds me intersectionality theory (Cole, 2009; Crenshaw, 1995). If I were a member of the mainstream, I would not have to bother trying to fit in to what I considered as the social norm. As regard to gender variance, it makes me wonder how differently the gender equilibrium would stand if people with other gender variations and orientations held power and privilege in our society?

\section{$\sim$ Elizabeth}

Your question on persons with gender variance holding power and privilege in society reminds me of the First Nations' two-spirit people. Two-spirit people from tribes such as the Navaho, where gender- or sex-variant, and sexually variant members of their tribes held esteemed roles and responsibilities such as, being leaders, medicine people, and intermediaries (Robinson, 2017). They were honored for having both feminine and masculine spirits or a blending of traditionally, female and male characteristics. Two-spirit women often went to war or hunted with the men and two-spirit men created pottery, wove baskets, and prepared food with the women (Robinson, 2017). Moreover, not only were two-spirit people revered, but they were allowed to blossom. Just think how much more healthy and happy our gay sons, lesbian daughters, gender-variant and intersex children would be if they could simply "be." If we could simply embrace and celebrate them for the talents and gifts they bring instead of shunning them. Today, homophobia and cisphobia, largely a legacy of colonialism, have seeped into the culture of the First Nations people.

You also asked me if I held certain presumptions of womanhood. Admittedly, my

Cultural and Pedagogical Inquiry, Summer 2018, 10(1), pp. 62-77

ISSN 1916-3460 (C) 2018 University of Alberta

http://ejournals.library.ualberta.ca/index.php/cpi/index 
presumptions were varied, contradictory, and unclear. Growing up as a Mormon, serving a mission in Japan, getting married in the temple, and later leaving the church over doctrinal issues, all helped to foster contradictory notions in me. At 29, I was ready to relearn what it meant to be woman. I based this re-creation of myself on feminist philosophies and interpretations. However, when my children became teenagers, views of my traditional upbringing surfaced and were often at odds with more modern views I held...

\section{Sunlight, Moonlight}

\section{$\sim$ Elizabeth}

... Maya Angelou's poem, "Phenomenal Woman" (Angelou, 1994), seems to depict true beauty, and not the vanity we see so much today. Where is that line drawn between vanity and beauty? When does one stop and the other begin?

\section{$\sim$ Ling}

Angelou's poem and your questioning the line between vanity and beauty pushed me to further reflect on my experience of learning about feminine beauty. I didn't consider myself naturally endowed with beauty so I let my boyfriend guide me to make myself more attractive. My purpose was to satisfy his perception of beauty and I have come to realize that his perception of beauty is cultivated by the mass media depicting an increasingly homogenized image of beautiful women, who are tall, slim, sensually curved, pale-skinned, with big eyes and a high bridged nose. Since a lot of TV shows were trying to create a sense of humour by contrasting such model beauties with plain-looking women, perhaps I was led to feel ashamed of looking ordinary. In fact, I felt the pressure to look beautiful because otherwise I would subject myself to limited chances of marrying a rich man and getting interviewed for a well-paying job.

With this in mind, I started "buying beauty": fashion magazines, whitening lotion, mascaras, jewelry, accessories, stylish outfits, to name just a few. Nevertheless, I wasn't very radical in this sense considering that more and more girls were referring to cosmetic surgeries for a physical makeover (Hua, 2013). The interpretations of my experience are best captured in Sun's (2017) article on the influence of capitalism on Chinese women's perception of beauty and their desire to become beautiful. Based on psychological analysis of human desire, Sun asserted that cosmetic surgeries serve not so much to satisfy one's own desire for beauty as to satisfy others' desire for and imagination of beauty. The question is: Who decides the beauty that others desire and imagine? Sun traced the answer to capitalism because it has turned beauty into a commodity to be bought and consumed, from which huge economic capital is generated. Meanwhile, beauty has also become a form of capital to be chased and utilized. Revisited from this perspective, my experience of learning about feminine beauty was not so much a process of learning to appreciate or discover the unique beauty of myself as a woman. The current situation seems that women have more freedom to choose how they look and more power to improve their life prospects, but have we really freed ourselves from the patriarchal chains? If beauty as capital becomes an additional prerequisite to distinction other than the economic, cultural, social and symbolic capital identified by Bourdieau (1986), wouldn't it be another burden to bear for women who can't afford to have it?

This motivated me to further inquire into the root cause of people's presumption of women's subordination. Elizabeth, I remember you asking me one day about Chinese feminism, which I had never thought of, and I came across the other day, a book on a preeminent Chinese

Cultural and Pedagogical Inquiry, Summer 2018, 10(1), pp. 62-77

ISSN 1916-3460 (C) 2018 University of Alberta

http://ejournals.library.ualberta.ca/index.php/cpi/index 
social theorist and anarcho-feminist He-Yin Zhen (1884-ca. 1920) and her feminist theories (Liu, Karl, \& Ko, 2013). Approached from a political economy framework, He's (1907a/2013) analyses are incisive and have confirmed my belief of capitalism's complicity in women's subordination. He's arguments are formed upon her discovery of a compelling analytical category of "nannü" (Liu et al., 2013). Literally, "nan" means "man" and "nü", "woman”. Nan and nü are found juxtaposed in some Chinese phrases like "nan nü you bie" meaning man and woman are different, or "nan nü shou bu qin" meaning man and woman should not be in direct contact with each other. However, according to He, the analytical implication of nannü as a whole concept cannot be captured by "nan and nü", or by nan or nü individually. It represents a dualist "mechanism of distinction" (Liu et al., 2013, p. 14) for the purpose of maintaining social hierarchy revolved around power and domination. It is inseparable from the Marxist notion of social class, and is in essence itself a generative category for social group division, thus a concept of class making. As I understand it, He deemed nannü, male/female or man/woman as a naming practice to categorize and distinguish nan, the dominating class from nü, the dominated class. People who are susceptible to the marking of nü are not confined to women, nor encompassing all women. They could include "poor women, young girls, slaves, and lower-class boys" (Liu et al., 2013, p. 17). Obviously, the category nü is attached with the qualities of weakness, which reminds me of Hamlet's soliloquy "frailty, thy name is woman" (Shakespeare, $1603 / 1998,1.2 .15)$. Nannü, then, is not a concept based on biological or sexual difference, but rather a socio-constructivist concept. However, the instrumentality of nannü is not so much about identifying differences either in biological or social terms, "which can never be settled" (Liu et al., 2013, p. 20). Instead, it is about reproducing the political need for social hierarchy. Therefore, the solution to women's oppression 'is not for 'woman' to become 'man', nor for 'man' to be the standard against which 'woman' and social justice are measured; rather, the solution is the elimination of this category of distinction as a metaphysical-political principle" (Liu et al., 2013, pp. 20-21).

He's (1907a/2013) insights struck me as fundamental and helped to ease some of my puzzles on the source of presumption of gender inequality. Apart from nannü, He (1907b/2013) discovered another analytical tool called "shengji," or literally put in English, livelihood. Shengji served her feminist lens with "a radical critique of capitalism, modernity, coloniality, the state, and imperial traditions" (Liu et al., 2013, p. 22). He argued that capitalism, with its aim of accumulating wealth and capital nationally and globally, requires the enslavement of women as men's private property and commodification of women's body. From the capitalist point of view, women's labor is deemed as an appropriable human capital, rather than as a basic human activity that is organic and autonomous to life itself. Therefore, He was critical of the advocacies for women's "freedom" because they did not touch on the fundamental issue of "inequality" in social relations.

He (1907a/2013, 1907b/2013) did not include gender variance in her analysis, but I think her criticism of the philosophy of dualism, capitalism and colonialism in contributing to the reproduction of an unequal social hierarchy can also account for people's inclination to subjugate gender variance. What I find unsettling is that after more than 100 years since He explicated her feminist theories, feminist struggles still persist today. As He pointed out, nannü has already been deeply entrenched as an ontology philosophically and reinforced philologically and historically through "millennia-long classical textual scholarship and Confucian commentarial traditions as well as legal, ritual, and social institutions in China" (Liu et al., 2013, p. 20). It has

Cultural and Pedagogical Inquiry, Summer 2018, 10(1), pp. 62-77 ISSN 1916-3460 (C) 2018 University of Alberta http://ejournals.library.ualberta.ca/index.php/cpi/index 
become "a normative distinction internal to patriarchal discourse . . capable of spawning new differences and new social hierarchies across the boundaries of class, age, ethnicity, race, and so on" (Liu et al., 2013, p. 14). With globalization, its reach has been extending transnationally, as you mentioned that homophobia and cisphobia have infiltrated the fa' afafine and the fakaleiti cultures. Isn't it another illustration of knowledge colonization?

Globalization has created new spaces for women to relearn their gender identity and gender roles. For me, I quit my job in Beijing and followed my husband who was seconded to work in Calgary two years ago, partly because I did not manage to conceive a baby after two years into marriage and I was worried about my inability to produce an heir. An ancient Confucian text reminds people that there are three ways of being an unfilial son, and the worst is failure to fulfill one's responsibility and show reverence to one's elders. People have distorted the text's original meaning by replacing "one's responsibility" with the sole responsibility of producing an heir. I felt the pressure from people around me, believing that having no child is worse than having no work. After, I gave birth to my baby, my husband's secondment in Calgary ended abruptly due to the economic downturn. We had to negotiate again our roles of childrearing, homemaking and work. He believed that it was for the family's best interest that I took care of the baby in Canada for a higher quality of life here while he would keep his job and work in China. Since he financially supported me to study here, I felt grateful that he "gave" me the opportunity for education. I also believed that I should give priority to my husband's career advancement and make sacrifices for the sake of the family. Thus, we formed a transnational family (Kobayashi \& Preston, 2007). Although I gave up my opportunity for work, assumed more responsibilities in childrearing and homemaking and juggled with the challenges of living in a foreign country while maintaining my relationship with my husband in China, my unpaid work at home was hardly acknowledged because it is traditionally considered "less significant" (Hayes, 2000, p. 38).

Kobayashi and Preston (2007) identified the "Asian familism" assumption among many Asians forming a transnational family. It espouses the values of: males over female family members; family over individual, or female individual's interests; and family members' welfare as being interdependent rather than dependent which is predicated on the profound Confucian preaching that women are subordinate to men (Samovar, Porter, McDaniel, \& Roy, 2012). However, the transnational family also provides a space that could potentially precipitate the relearning of gender identity. This is the case for me...

\section{Reflections}

\section{$\sim$ Elizabeth}

I went on intuition that Ling would be the perfect person to partner with to write a duoethnography. We have both felt the sting of sexism and have navigated through a world that has been largely created by and for men. It has only been during the last one hundred years that women have had the right to vote (New Zealand being the first in 1889, Canada in 1917, the US in 1920, and China in 1949), to experience freedoms and address issues of exploitation. I was aware that colonialism had largely tainted the customs of the fa'afafine of Samoa and two-spirit people, but I had tied such negative impacts to Christianity. I also recognized capitalism's tie to the commodification of beauty, but I had not considered capitalism's influence on gender identity development. I am grateful that Ling introduced me to the Chinese feminist author He $(1907 \mathrm{a} / 2013,1907 \mathrm{~b} / 2013)$. It forces me to turn my gender lens to analyze the capitalist system in Cultural and Pedagogical Inquiry, Summer 2018, 10(1), pp. 62-77 ISSN 1916-3460 @ 2018 University of Alberta http://ejournals.library.ualberta.ca/index.php/cpi/index 
which I am surrounded. Such an analysis challenges me to recognize a system of abuse and further, to acknowledge that I am immersed in and a product of it. I will read more of He's work to explore her ideas for my own work on gender and gender variance.

During the time that I've written this article with Ling, I have had the experience of turning my gaze on gender and have let the research "percolate in the subconscious"... Stepping back and reading about how cultures embrace gender variations has helped me to understand that although identity variations exist in all cultures, it is people who ultimately, determine how to react to and treat such identity variations (i.e. Brinkman et al., 2012; Brown, 2017; Butler, 2004; Davis, 2003, 2016; Farran,1997; Jenkins, 2015; Queer, 2017; Vasey \& Vanderlaan, 2009).

I leave this writing of a duoethnography with the optimistic view that culture is malleable. In my own lifetime, I have seen homosexuality go from being whispered gossip to legalized marriage in the US in 2015. I have seen women rise to positions of authority in corporations, universities, and governments. The world is not perfect, but these are examples of significant alterations in mindset during my own lifetime. Changes happen because of the vision of a marginalized and enlightened few who share their vision through much talk, time, and toil.

\section{$\sim$ Ling $\sim$}

This duoethnographic dialogue provided a space for me to reconceptualise my own experiences and the. culture in which I was socialized with Elizabeth, a critical friend (Hendricks, 2016; Norris \& Sawyer, 2012). Being a classmate and friend, Elizabeth left me with the ability to confide in her and share my personal experiences and innermost feelings. More importantly, being a co-researcher, she constantly challenged me to probe deeper into the experiences and feelings as sites for exploring the topic of gender identity (Oberg \& Wilson, 2002). As Elizabeth and I shared substantially different, personal and cultural experiences, the juxtaposition of our stories and insights helped me engage in a relational meaning-making process, in which my particular socio-economic status and the Chinese culture emerged as two significant factors in shaping my perceptions of gender.

By listening to Elizabeth's stories, I realized not only that mine were informed by a specific socio-historical context, but also that gender inequality and gender role rigidity issues were shared in various contexts. Thus, this dialogue enabled me to step simultaneously, into and away from my own previously-held perspectives. In doing so, to engage in a process that contributed to the metacognition of the fundamental roots of gender issues.

At the emotional level, I concur with Ellis (1997) that narrative writing can be "therapeutic" (p. 120). I seemed to have become gradually reconciled with the traumatic childhood experiences, which were, I believe, ineluctably attributed to the historical and socioinstitutional forces beyond individual control. I would also argue that such narrative writing is empowering. Having become more conscious of those forces, I became aware of adopting a more fundamental and holistic approach to address gender issues rather than linger on lamenting women's oppression.

I also hope that my stories served as the "foil" (Norris \& Sawyer, 2012, p. 10) for Elizabeth to embark on yet another, reflective and evolving learning journey of her life. I can see that she has already learned, admittedly through tears, the beauty of womanhood, which I still seek to discover. The cross-cultural experience in Japan has made her question the weight of 
patriarchy on her. Reflections on and the eventual rejection of the doctrines of her Mormon religion brought her the opportunity to relearn gender while navigating her own identity as a woman and mother of a transgender child. However, her learning process was never neat. Rather, it seemed to me messy, murky, and full of confusion and contradictions.

As I understand it, challenging patriarchy's social norms and a society's gender binary, demand great courage and arduous efforts, because they are so deeply entrenched in others and ourselves. Nevertheless, I can see that Elizabeth has gained more confidence to move forward through this dialogic research. She is finding allies in her fight against gender binary in her continuing research, in hearing that young men have conversations about gender stereotypes and are learning to take off the imposed masks of masculinity, and hopefully, too, from my stories. Personal and people's stories are empowering. They are evidence that gender diversity is not only a vision, it has already been successfully practiced, revered, and promoted. I like the way Elizabeth encourages me to imagine how much healthier and happier gender-marginalized children would be if they could simply be themselves. Finally, Elizabeth encourages me to wonder just how much and what feminine beauty could be if owned by ourselves, as women. The constant imagining of alternative sand possibilities are like beacons of hope for both of us navigating through our passages of womanhood and life. 


\section{References}

Alicia, G. F. \& Dick, F. S. (2008). A sex difference in the hypothalamic uncinate nucleus: Relationship to gender identity. Brain: A Journal of Neurology, 131(12), 3132-3132.

Angelou, M. (1994). Phenomenal woman: Four poems celebrating women. New York: Random House.

Boss, P. (2000). Ambiguous loss: Learning to live with unresolved grief (1st Harvard University Press pbk. ed.). Cambridge, MA: Harvard University Press.

Boss, P. (2017). Four questions about ambiguous loss. Retrieved from: http://www.ambiguousloss.com/four questions.php

Bourdieu, P. (1986). The forms of capital. In J. Richardson (Ed.), Handbook of theory and research for the sociology of education (pp. 241-258). New York, NY: Greenwood.

Brinkman, B. G., Rabenstein, K. L., Rosén, L. A., \& Zimmerman, T. S. (2012). Children gender identity development. Youth \& Society, 46(6), 835-852. doi:10.1177/0044118X12455025

Brown, C. (2017). Making a man: How does a 21st-century boy reach manhood? National Geographic (January).

Butler, J. (2004). Undoing gender. New York: Routledge, Taylor \& Francis Group.

Cole, E. R. (2009). Intersectionality and research in psychology. American Psychologist, 64(3), 170-180. doi:10.1037/a0014564

Crenshaw, K. W. (1995). Mapping the margins: Intersectionality, identity politics, and violence against women of color. In K. W. Crenshaw, N. Gotanda, G. Peller, \& K. Thomas (Eds.), Critical race theory: The key writings that formed the movement (pp. 359-383). New York, NY: New Press.

Davis, W. (2003). Wade Davis: Dreams from endangered cultures. Paper presented at the TED: Ideas Worth Sharing, Monterey, CA.

Davis, W. (2016). The mask of masculinity. Paper presented at the TEDxUF, Gainesville, FL.

Edwards, K. E. \& Jones, S. R. (2009). "Putting my man face on": A grounded theory of college men's gender identity development. Journal of College Student Development, 50(2), 210 228.

Ellis, C. (1997). Evocative autoethnography: Writing emotionally about our lives. In W. G. Tierney \& Y. S. Lincoln (Eds.), Representation and the text: Re-framing the narrative voice (pp. 115-139). Albany, NY: State University of New York Press.

Fan, H. (1997). Footbinding, feminism and freedom: The liberation of women's bodies in modern China. London, UK: Frank Cass. 
Farran, S. (2010). Pacific perspectives: Fa'afafine and fakaleiti in Samoa and Tonga: People between worlds. Liverpool Law Review, 31(1), 13-28. doi:10.1007/s10991-010-9070-0

Government of Canada, Status of Women Canada. (2016). The national day of remembrance and action on violence against women. Retrieved from:

http://www.swc-cfc.gc.ca/commemoration/vaw-vff/remembrance-commemoration-en.html

Gramsci, A. (1994). Letters from prison. New York: Harper \& Row.

Hayes, E. (2000). Social contexts. In E. Hayes \& D. D. Flannery (Eds.), Women as learners: The significance of gender in adult learning (pp. 23-52). San Francisco, CA: Jossey-Bass.

He, Y. (2013a). On the question of women's liberation. In L. H. Liu, R. Karl, \& D. Ko (Eds. \& Trans.), The birth of Chinese feminism: Essential texts in transnational theory (pp. 5371). New York, NY: Columbia University Press. (Original work published 1907).

He, Y. (2013b). On the question of women's labor. In L. H. Liu, R. Karl, \& D. Ko (Eds. \& Trans.), The birth of Chinese feminism: Essential texts in transnational theory (pp. 7291). New York, NY: Columbia University Press. (Original work published 1907).

Hendricks, C. (2016). Improving schools through action research: A reflective practice approach (4th ed.). Upper Saddle River, NJ: Pearson Education.

Heron, J. (1981). Philosophical basis for a new paradigm. In P. Reason \& J. Rowan (Eds.), Human inquiry, a sourcebook of new paradigm research. Chichester: Wiley.

Holmes, L. D. (2000). [Paradise Bent, Heather Croall]. American Anthropologist, 102(3), 604-605.

Hua, W. (2013). Buying beauty: Cosmetic surgery in China. HK, China: HKU Press.

Jarvis, P. (2006). Towards a comprehensive theory of human learning: Lifelong learning and the learning society, Volume 1. New York, NY: Routledge.

Jenkins, A. (2015). Critical conversations: Dialogue in global citizenship education. Widening Participation and Lifelong Learning, 17(2), 30-47. doi:10.5456/wpll.17.2si.30

Kobayashi, A. \& Preston, V. (2007). Transnationalism through the life course: Hong Kong immigrants in Canada. Asia Pacific Viewpoint, 48(2), 151-167. doi:10.1111/j.14678373.2007.00338.x

Krammer, D. \& Mangiardi, R. (2012). The hidden curriculum of schooling: A duoethnographic exploration of what schools teach us about schooling. In J. Norris, R. D. Sawyer, \& D. E. Lund (Eds.), Duoethnography: Dialogic methods for social, health, and educational research (pp. 41-70). New York, NY: Routledge.

Lawson, D. M. (2013). Family Violence: Explanations and Evidence-Based Clinical Practice. Alexandria, VA: American Counseling Association.

Liao, L., Audi, L., Magritte, E., Meyer-Bahlburg, H. F., \& Quigley, C. A. (2012). Determinant factors of gender identity: A commentary. Journal of Pediatric Urology, 8(6), 597-601. doi:10.1016/j.jpurol.2012.09.009

Cultural and Pedagogical Inquiry, Summer 2018, 10(1), pp. 62-77

ISSN 1916-3460 (C) 2018 University of Alberta

http://ejournals.library.ualberta.ca/index.php/cpi/index 
Liu, L. H., Karl, R. E., \& Ko, D. (Eds.). (2013). The birth of Chinese feminism: Essential texts in transnational theory. New York, NY: Columbia University Press.

Lund, D. E. \& Evans, R. E. (2006). Opening a can of worms: A duo-ethnographic dialogue on gender, orientation, and activism. Taboo: The Journal of Culture \& Education, 10(2), 55-67.

Madison, D. (2012). Critical ethnography: Method, ethics, and performance. Thousand Oaks, CA: Sage.

Norris, J. \& Sawyer, R. D. (2012). Toward a dialogic methodology. In J. Norris, R. D. Sawyer, \& D. E. Lund (Eds.), Duoethnography: Dialogic methods for social, health, and educational research (pp. 9-38). New York, NY: Routledge.

Oberg, A. \& Wilson, T. (2002, December). Side by side: Being in research autobiographically. Educational Insights, 7(2). Retrieved from: http://einsights.ogpr.educ.ubc.ca/v07n02/contextualexplorations/wilson_oberg/

Pascoe, C. J. (2007). Dude, you're a fag: Masculinity and sexuality in high school. Sexualities. Berkeley: University of California Press.

Queer [Usage note]. (2017). American Heritage Dictionary. Houghton Mifflin Harcourt.

Samovar, L. A., Porter, R. E., McDaniel, E. R., \& Roy, C. (2012). Communication between cultures (8th ed.). Boston, MA: Wadsworth Cengage Learning.

Shakespeare, W. (1998). The tragedy of Hamlet: Prince of Denmark. S. Barnet (Ed.). New York, NY: Penguin Group. (Original work published 1603).

Sun, J. (2017, March 2). Ni da jin lian de bu shi bo niao suan, shi zi ben [What is injected into your face is not hyaluronic acid, but capital]. Retrieved from: http://dajia.qq.com/original/category/sxj20170302.html

Vasey, P. L. \& VanderLaan, D. P. (2009). Materteral and avuncular tendencies in Samoa. Human Nature, 20(3), 269-281. doi:10.1007/s12110-009-9066-4

Wall, S. (2006). An autoethnography on learning about autoethnography. International Journal of Qualitative Methods, 5(2), 146-160. doi:10.1177/160940690600500205 